〔J.'Appl. Glycosci., Vol. 46, No.2, p. 111-119 (1999)〕

\title{
Differences in Sugar Regulation between Two Isoforms of $\alpha$-Amylase in Suspension-Cultured Cells of Rice
}

\author{
Naomi Geshi, Toshiaki Mitsui, ${ }^{1}$ Takashi Akazawa and Junji Yamaguchi* \\ Bioscience Center and Graduate School of Bioagricultural Sciences, Nagoya University \\ (Chikusa, Nagoya 464-8601, Japan) \\ ${ }^{1}$ Department of Applied Biochemistry, Faculty of Agriculture, Niigata University \\ (Igarashi-2, Niigata 950-2181, Japan)
}

\begin{abstract}
Tissue-specific expression of the isoforms of rice $\alpha$-amylase and their expression in suspensioncultured cells were investigated, together with regulation by various sugars. Six isoforms, Y, A, G, H, $\mathrm{I}$ and $\mathrm{J}$, were identified: isoform $\mathrm{A}$, isoform $\mathrm{Y}$ and isoforms $\mathrm{A}-\mathrm{J}$ were mainly detected in germinating seeds, young plant tissues, and suspension-cultured cells, respectively. From the results of amino acid sequencing of the purified isoforms, isoform $\mathrm{A}$ and isoform $\mathrm{H}$ were identified as the gene products of $R A m y 1 A$ and $R A m y 3 D$, respectively (Plant Physiol., 110, 1395-1404 (1996)). Since metabolic regulation of the expression of rice $\alpha$-amylase has been reported, we analyzed this phenomenon by following the changes in levels of each isoform in cells in suspension cultures in the presence of various sugars. The expression of the $R A m y 3 D$-encoded protein (isoform $\mathrm{H}$ ) was completely repressed by so-called metabolic sugars, while expression of the $R A m y 1 A$-encoded protein (isoform $\mathrm{A}$ ) was repressed to a less extent. The results indicate that high expression of the $R A m y 3 D$-encoded protein is controlled much differently from that of the RAmy1A-encoded protein.
\end{abstract}

During the germination of cereal grains, $\alpha$ amylases (EC 3.2.1.1) play a key role in the mobilization of the energy reserves constituted by insoluble starch granules. ${ }^{1)}$ This enzyme catalyzes the hydrolysis of $\alpha-1,4$ glucan bonds of starch in germinating cereals. Experimental evidence provided'by activity staining in situ, ${ }^{2)}$ detection of $\mathrm{mRNA}^{3,4)}$ and functional promoter analysis using transgenic rice ${ }^{5)}$ have demonstrated that the biosynthesis of $\alpha$-amylase is initiated in the scutellar epithelium, and then it occurs in the aleurone layer at later stages of germination. There are many reports that biosynthesis of the enzyme is regulated by gibberellin and abscisic acid at the transcriptional level. ${ }^{1)}$ However, most of the results were indicated from the biosynthesis of $\alpha$-amylase in the aleurone layer cells. Studies on biosynthesis and its regulatory mechanisms of $\alpha$ amylase in the scutellar epithelium have

\footnotetext{
${ }^{*}$ Corresponding author.
}

remained controversial up to the present.

Huang et $a l .{ }^{6)}$ reported that genes for $\alpha$ amylase in rice form a family of ten genes located on five different chromosomes. These genes have been classified into three subfamilies, namely, $R A m y 1 A, 1 B$ and $1 C$; $R A m y 2 A$; and $R A m y 3 A, 3 B, 3 C, 3 D, 3 E$ and $3 F$ (and another nomenclature also used by $\mathrm{Yu}$ et $\left.a l .{ }^{7}\right)$ ). DNA sequence analysis of 17 plant genes for $\alpha$-amylase has revealed that cereal genes for $\alpha$-amylase fall into two major classes, AmyA and AmyB. The AmyA class can be subdivided into the Amy1 (high $\mathrm{p} I$ ) and Amy2 (low $\mathrm{p} I$ ) subfamilies that were previously used to classify genes for $\alpha$-amylase in rice, barley and wheat. The AmyB class includes the Amy3 subfamily to which most of the $\alpha$-amylase genes of rice belong. Several $\alpha$-amylase isoforms are encoded by multigene families in cereals. In barley, isoforms of $\alpha$-amylase are classified as having a low isoelectric point $(\mathrm{p} I)$ or a high $\mathrm{p} I$, with each group consisting of multiple iso- 
forms. ${ }^{8)} \quad$ Analysis with isoelectric focusing gels revealed at least three isoforms of $\alpha$-amylase (bands A, B and D) in extracts of germinating rice seeds. ${ }^{9)}$ We identified ten $\alpha$-amylase isoforms (isoforms A, B, E, F, G, H, I, J, Y and Z) from suspension-cultured rice cells having different isoelectric point values. These isoforms would be encoded by various members of the $\alpha$-amylase gene families. From the results of amino acid sequencing of the purified isoforms, isoform $\mathrm{A}$ and $\mathrm{B}$ and isoform $\mathrm{D}$ and $\mathrm{E}$ were identified as the gene products of $R A m y 1 A$ and $R A m y 3 D$, respectively. ${ }^{10)}$

In rice, the modulation of $\alpha$-amylase genes by carbohydrates and other metabolites has been well described..$^{71-13)}$ At least ten genes encode for $\alpha$-amylase isoforms in rice, but two of them are strongly under the control of the sugar level, namely $R A m y 3 D$ and $R A m y 3 E$ (also identified as $\alpha$ Amy3 and $\alpha$ Amy 8$),{ }^{7,14,15)}$ although the gibberellin-inducible $R A m y 1 A$ gene is modulated by sugars. ${ }^{16)}$

In this report, as a further characterization of rice $\alpha$-amylase isoforms, we describe the tissuespecific expression of the isoforms and the distinct profiles of expression of the isoforms (RAmy1A-encoded and RAmy3D-encoded proteins) in response to metabolizable sugars in suspension-cultured cells. Our results indicate that the $R A m y 3 D$-encoded protein has characteristics very different from those of the $R A m y 1 A$-encoded protein.

\section{MATERIALS AND METHODS}

Cultures of rice cells. Rice calli were generated from embryonic scutella of the rice cells (Oryza sativa L. cv. Nipponbare). ${ }^{17)}$ Rice seeds were dehulled and surface-sterilized with a $3 \%$ solution of $\mathrm{NaClO}$ that contained $0.1 \%$ Tween 20 for $30 \mathrm{~min}$ and they were then washed extensively with sterile distilled water. The washed seeds were placed on agar-solidified medium that contained $1 \%$ agar, inorganic salts of $\mathrm{R} 2$ medium, ${ }^{18)} 5.6 \mathrm{mg} / \mathrm{L} \mathrm{FeSO}_{4}, 7.5 \mathrm{mg} / \mathrm{L} \mathrm{Na}{ }_{2}$ EDTA, the vitamins of MS medium, ${ }^{19)} 2.0 \mathrm{mg} / \mathrm{L}$ glycine, $2.0 \mathrm{mg} / \mathrm{L} \quad$ 2,4-dichlorophenoxy-acetic acid (2,4-D) and $3 \%(\mathrm{w} / \mathrm{v})$ sucrose. Embryonic cultures were incubated at $30^{\circ} \mathrm{C}$ under continu- ous white light (2,000 lux). Four weeks later, the resultant calli were transferred to a liquid medium with the same ingredients as the solid medium described above but without agar. Approximately $0.5 \mathrm{~g}$ fresh weight of calli were cultured in $20 \mathrm{~mL}$ of medium in a $100-\mathrm{mL}$ Erlenmeyer flask. The suspension culture was shaken on a reciprocal shaker at $120 \mathrm{rpm}$ and incubated at $25^{\circ} \mathrm{C}$ under constant light $(2,000$ lux). Established suspension-cultured cells were subcultured every 7 days by the transfer of $2 \mathrm{~g}$ fresh weight of cells into $200 \mathrm{~mL}$ of fresh liquid suspension medium in a $500-\mathrm{mL}$ flask. All procedures were carried out under aseptic conditions. For experiments, 3-day-old cultures were used for the initiation of analyses and experiments were performed at a concentration of $1 \mathrm{~g}$ fresh weight of cells per $40 \mathrm{~mL}$ of fresh liquid suspension medium.

Zymogram of $\alpha$-Amylase. Isoelectric focusing was performed with a Multiphor II Electrophoresis system (Pharmacia-LKB, Uppsala, Sweden) in accordance with the instructions from the manufacturer. Electrophoresis was performed on Ampholine gels (Ampholine PAG Plate; $\mathrm{pH}$ range $3.5-9.5$; Pharmacia-LKB) at $1500 \mathrm{~V}$ for $1.5 \mathrm{~h}$ at $10^{\circ} \mathrm{C}$. After isoelectric focusing, gels were incubated in a $1 \%$ solution of $\beta$-limit dextrin in $50 \mathrm{~mm}$ sodium acetate buffer that contained $10 \mathrm{mM} \mathrm{CaCl}_{2}$ (pH 5.2) for $2 \mathrm{~h}$. After soaking in distilled water, gel was incubated in a solution of $1.3 \% \mathrm{I}_{2}$ and $3 \% \mathrm{KI}$ for the detection of $\alpha$-amylase activity. ${ }^{9)}$

Extraction of protein. Rice tissues were extracted with $50 \mathrm{~mm}$ Tris- $\mathrm{HCl}$ buffer ( $\mathrm{pH}$ 7.5, $10 \mathrm{mM} \mathrm{CaCl}_{2}, 0.1 \%$ Triton X-100). The following extraction ratios (tissues/buffer $=\mathrm{w} /$ v) were used for the different materials: shoots and roots, $1 / 2$; embryos, $1 / 5$; endosperm, 1/5; and calli, $1 / 5$. The extracts were centrifuged at $13,000 \times g$ for $15 \mathrm{~min}$ at $4{ }^{\circ} \mathrm{C}$ and the supernatants were used for zymograms or quantitation of $\alpha$ amylase activity.

Isolation of RNA and dot blotting. Total RNA was extracted from suspension-cultured cells of rice by the phenol/SDS method described by Karrer et $a l .{ }^{20)}$ Concentrations of RNA were determined spectrophotometrically and verified by ethidium-bromide staining of the 
agarose/formaldehyde gels.

Dot blotting was performed on Nytran membranes (Schleicher \& Schuell, Keene, NH, USA). Prehybridization was performed in $5 \times$ SSPE, $5 \times$ Denhardt's solution, $50 \%$ deionized formamide, $1 \%$ SDS and $150 \mathrm{mg} / \mathrm{mL}$ sheared salmon-sperm DNA at $42^{\circ} \mathrm{C}$ for at least $4 \mathrm{~h}$. Membranes were probed with ${ }^{32} \mathrm{P}$-labeled DNA fragments derived from cDNA clones of rice $\alpha$ amylase, pOS103 or pOS137..$^{20}$ Hybridization was carried out for $20 \mathrm{~h}$ at $61^{\circ} \mathrm{C}$ in prehybridization solution followed by two successive 30 min washes in $0.1 \times \mathrm{SSPE} / 0.1 \% \mathrm{SDS}$ at $65^{\circ} \mathrm{C}$. This procedure was effective for the detection of gene-specific mRNA for rice $\alpha$-amylase because of limited cross-hybridization among the mRNAs.

Radioactivity on filters was detected with a Fujix BAS 2000 image analyzer (Fuji Photo Film Co. Ltd., Tokyo, Japan).

Assays of enzymatic activities. $\alpha$-Amylase activities were determined by the method of Perata et $a l^{21)}$ One unit of $\alpha$-amylase was defined as the amount of enzyme producing a $10 \%$ decrease in the absorbency of the control reaction mixture (0-min incubation) within 10 min. Concentrations of sucrose, glucose and fructose in the medium were analyzed enzymatically by the method of Guglielminetti et $a l{ }^{22)}$ Protein concentrations were determined with a protein assay kit from Bio-Rad (Watford, Herts., UK) with $\gamma$-globulin as the standard.

\section{RESULTS}

Tissue-specific expression of isoforms of $\alpha$ amylase in rice.

The isoforms of $\alpha$-amylase with distinct $\mathrm{p} I$ values in different tissues of rice were separated by isoelectric focusing, as shown in Fig. 1. In 12-day-old suspension-cultured cells (lane 1), five main activity bands of $\alpha$-amylase, designated isoforms A, G, H, I and J, were observed. Isoform $\mathrm{A}$ was also detected in the endosperm (lane 2) and embryos (lane 3) dissected from 3day-old seeds. We confirmed that isoform A was identical to bands $\mathrm{A}$ and $\mathrm{B}$ reported previously as the "isozymes" of rice $\alpha$-amylase in germinating seeds. ${ }^{9,23)}$ By contrast, single

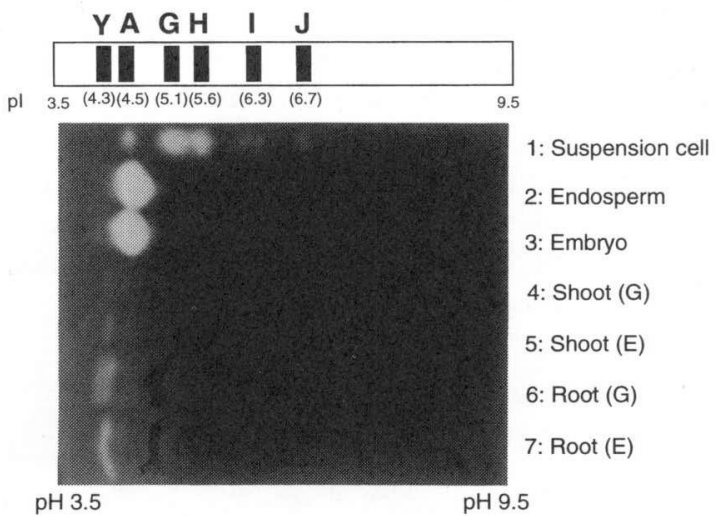

Fig. 1. Separation of isoforms of rice $\alpha$-amylase by isoelectric focusing.

Samples were: lane 1, 12-day-old suspension cultured cells; lanes 2 and 3, endosperm and embryos from 3-daygerminating seeds; lanes 4 and 6 , shoots $(G)$ and roots (G) of 14-day-old seedlings grown in the light; and lanes 5 and 7 , shoots (E) and roots (E) of 14-day-old seedlings grown in the dark. Samples (1 $\mu$ g protein for lane 1, 40 $\mu \mathrm{g}$ for the other lanes) were separated by isoelectric focusing $(\mathrm{pH} 3.5-9.5)$ and the gel was stained after incubation with $\beta$-limit dextrin as described in the text. The tentative nomenclature (isoforms $\mathrm{Y}, \mathrm{A}, \mathrm{G}, \mathrm{H}$, $\mathrm{I}$ and $\mathrm{J}$ ) is summarized at the top of the figure with $\mathrm{p} I$ values. (Isoforms Y, A and I were detected in double or multiple form on a narrow $\mathrm{pH}$ range gel.)

(lanes 4, 5,7) or double (lane 6) bands designated isoform $\mathrm{Y}$, with a lower $\mathrm{p} I$ than isoform $\mathrm{A}$, were obtained from the shoots and roots of 14 day-old seedlings cultivated under both light and dark conditions. Consequently, a tentative nomenclature for the isoforms (Y, A, G, H, I, and $\mathrm{J}$ ) was developed as shown at the top of Fig. 1. Furthermore, the tissue-specific expression of the major isoform (s) was determined as follows: (1) isoform A was expressed in germinating seeds; (2) isoforms A, G, H, I, and J were expressed in suspension-cultured cells; and (3) isoform Y was specific to the shoots and roots of young plants. We also detected the presence of multiple minor bands of $\alpha$-amylase activity, which may also play an important physiological role. ${ }^{10)}$

The pattern of $\alpha$-amylase isoforms from suspension-cultured cells of rice was similar to that from isolated embryos in rice. ${ }^{24)}$ We performed amino acid sequencing of purified isoforms $\mathrm{A}, \mathrm{G}$ and $\mathrm{H}$ aiming to compare the results 
with the amino acid sequences deduced from nucleotide sequences of rice genes for $\alpha$-amylase. ${ }^{10)}$ The analysis revealed that isoforms A and $\mathrm{H}$ were translated protein products of the $R A m y 1 A$ and $R A m y 3 D$ genes, respectively. Further analysis for amino acid sequencing of purified isoforms showed that isoform $\mathrm{G}$ is also a gene product of $R A m y 3 D$.

A

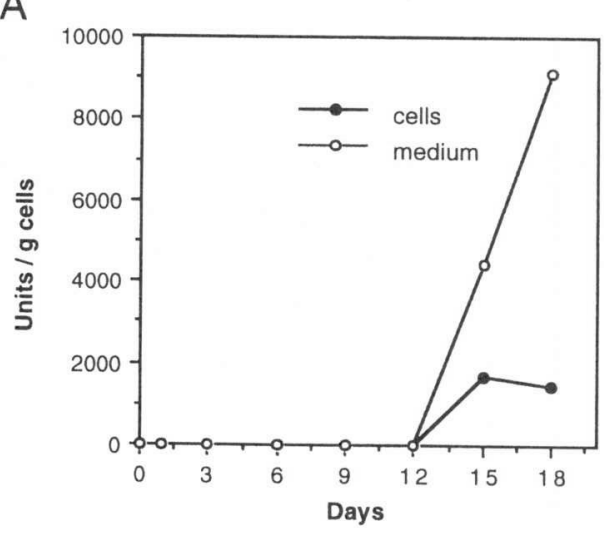

B

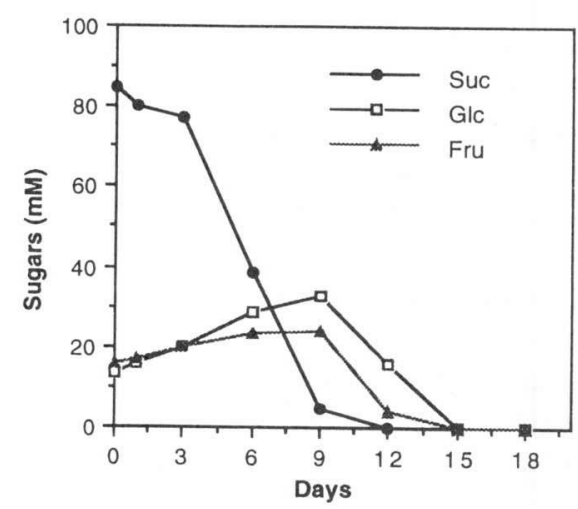

Differences in responses to metabolic sugars between isoform A (RAmy1A-encoded protein) and isoform $H$ (RAmy3D-encoded protein).

$\alpha$-Amylase was synthesized de novo in suspension-cultured cells derived from rice embryos. ${ }^{10,25-27)} \quad$ Time-course experiments showed that the activity of $\alpha$-amylase could be detected after a 12-day incubation in both a cell extract and the culture medium (panel $\mathrm{A}$ in Fig. 2). The activity in the cells reached about 1500 units/g of cells after a 15-day incubation while a continuous increase in the activity in the

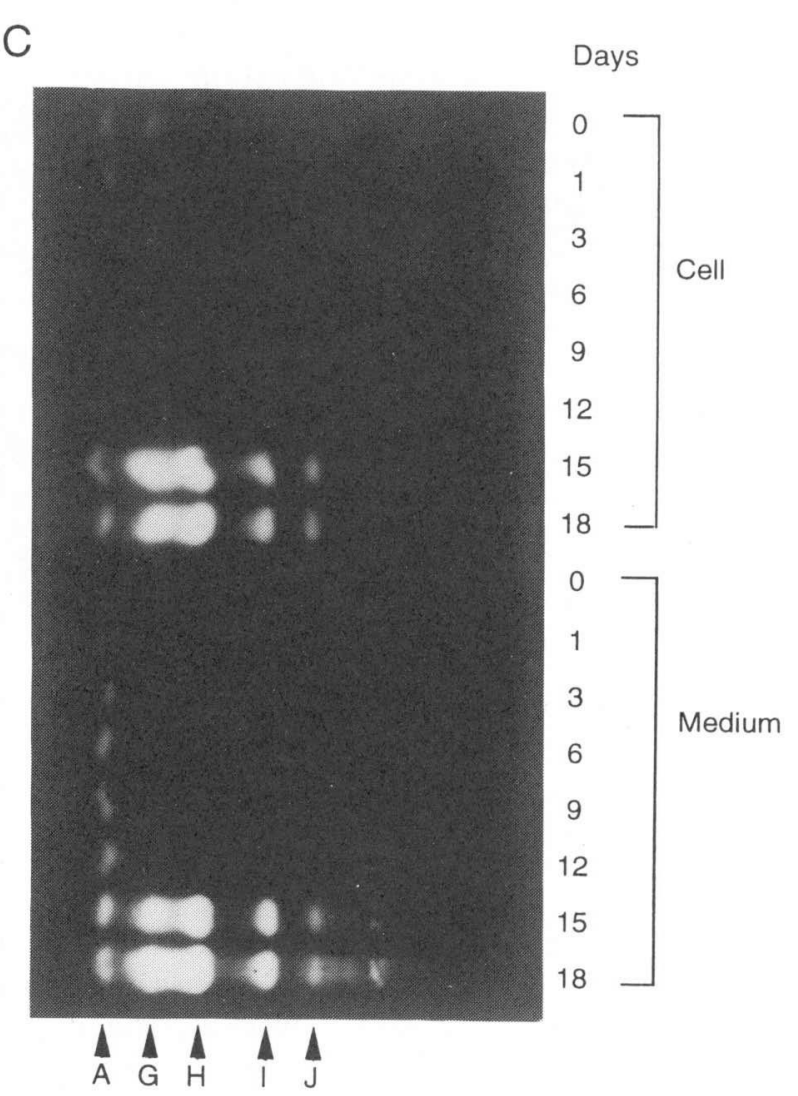

Fig. 2. Time-course analysis of the growth of cells in suspension culture.

Rice cells were cultured in suspension medium that contained $3 \%$ sucrose $(0.09 \mathrm{M})$ for 18 days. At 3 -day intervals, cells and medium were sampled; cells were weighed and subsequently ground with buffer to extract proteins. Panel A : Changes in the activity of $\alpha$-amylase. The activity is expressed as units/g cells ( Activity units for medium are defined as the activity (units) secreted into medium per g cells. Panel B: Analysis of carbohydrates in the medium. Sucrose $(\mathbf{)})$, glucose $(\square)$ and fructose $(\mathbf{\Delta})$. Panel C: Changing profiles of $\alpha$-amylase isoforms (A, G, H, I and J) in cells (upper part) and in culture medium (lower part). Samples (15 $\mu \mathrm{g}$ protein for the cells, $10 \mu \mathrm{L}$ for the medium) were subjected to isoelectric focusing (pH 3.5-9.5) and the gel was stained after incubation with $\beta$-limit dextrin. 
culture medium was observed, an indication that the synthesized enzyme is actively secreted into the medium. The concentration of sucrose remained constant for the first 3 days and subsequently decreased dramatically to an undetectable level by day 12 (panel B in Fig. 2). The glucose and fructose detected in the medium on day 0 may to be the result of hydrolysis of sucrose during autoclaving. The concentrations of both increased in a similar fashion until day 9 , suggesting further hydrolysis of sucrose. The levels of both glucose and fructose decreased after day 9 and they were undetectable on day 15. As shown in panels $\mathrm{A}$ and $\mathrm{B}$, the total activity of $\alpha$-amylase increased markedly when the cells were subjected to sugar starvation. The levels of each of the isoforms of $\alpha$ amylase during the experiment are shown in panel $\mathrm{C}$. Isoforms $\mathrm{A}-\mathrm{J}$ were synthesized de novo from day 12 to day 15, in agreement with the results for total activity (panel A). We also observed that the $R A m y 1 A$-encoded protein (isoform A) was expressed and secreted before day 12 , while the others, including the $R A m y 3 D$-encoded protein (isoform $\mathrm{H}$ ), were not detected until day 12 . This result indicates that the expression of the RAmy $1 A$ and $R A m y 3 D$ genes is regulated differentially, with the $R A m y 3 D$ gene being completely repressed in the presence of sucrose while the $R A m y 1 A$ gene is not. This hypothesis is consistent with the observation that the level of mRNA transcribed from the $R A m y 3 D$ gene in the isolated scutella of rice was negatively influenced by the presence of glucose. ${ }^{12,15)}$

We confirmed that sucrose is a factor that triggered the repression of isoforms $\mathrm{A}-\mathrm{J}$ by transferring cells to either sucrose-free medium (panel A in Fig. 3, lanes 1-3) or sucrose-containing medium (lanes 4-6). The monosaccharides glucose (lanes 7-9) and fructose (lanes 10-12), as well as the disaccharide sucrose, were all effective in repressing the isoforms at a concentration of $0.09 \mathrm{M}$. To control the effects of osmotic shock on the expression of the isoforms, the cells were incubated in mannitol at equivalent molarity (lanes 13-15). The levels of isoforms $\mathrm{A}-\mathrm{J}$ remained relatively constant compared with those after sucrose depletion
A
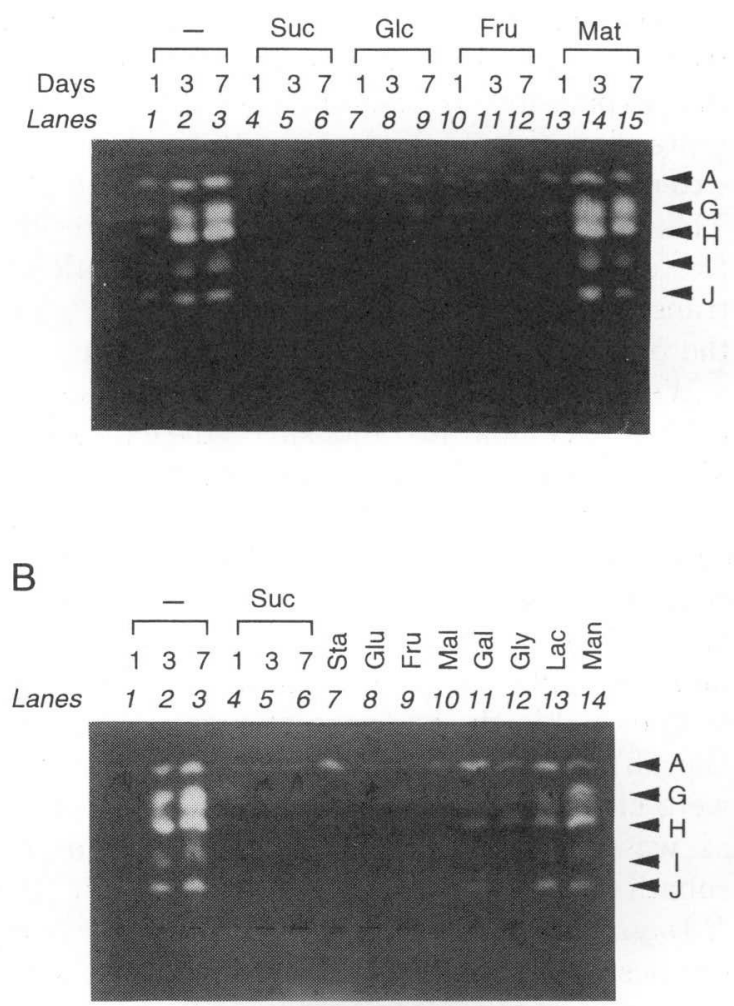

Fig. 3. Effects of various sugars on the expression of isoforms $\mathrm{A}-\mathrm{J}$ of $\alpha$-amylase.

Panel A: Suspension-cultured cells of rice, grown in culture medium that contained $0.09 \mathrm{M}$ sucrose for 3 days, were transferred to fresh medium that contained different sugars as indicated and culturing was continued for an additional 7 days: lanes $1-3$, no sugar $(-)$; lanes 4-6, $0.09 \mathrm{M}$ of sucrose (Suc); lanes 7-9, glucose (Glc); lanes 10-12, fructose (Fru); and lanes 13-15, mannitol (Mat). Cells were collected at different times ( 1 day, 3 days and 7 days) and proteins were extracted. Samples $(15 \mu \mathrm{g}$ protein) were subjected to isoelectric focusing ( $\mathrm{pH} 3.5-9.5)$ and the gel was stained after incubation with $\beta$-limit dextrin. Panel B: Experimental conditions are the same as those described for panel A. Suspension-cultured cells of rice grown in culture medium that contained $0.09 \mathrm{~m}$ sucrose for 3 days were transferred to fresh medium that contained: lanes 1-3, no sugar (-); or lanes 4-6, 0.09 $\mathrm{m}$ sucrose (Suc), and cultured for 7 days. The cells were also transferred to the medium that contained $1 \%(\mathrm{w} / \mathrm{v})$ soluble starch (lane 7) or $0.09 \mathrm{M}$ glucose (lane 8), fructose (lane 9), maltose (lane 10), galactose (lane 11), glycerol (lane 12), lactose (lane 13) and mannose (lane 14), and after a 3-day incubation the cells were collected and homogenized to extract proteins. Samples (15 mg protein) were subjected to isoelectric focusing $(\mathrm{pH} 3.5-9.5)$ and the gel was stained after incubation with $\beta$-limit dextrin. 
(lanes 1-3). These results imply that metabolizable sugars, namely, sucrose, glucose and fructose, might be signal molecules that repress the expression of isoforms $\mathrm{G}^{-} \mathrm{J}$, while the repression of isoform $\mathrm{A}$ seems to be to a lesser extent compared to other isoforms (lanes 4-12). This hypothesis is in agreement with the results for total $\alpha$-amylase proteins, ${ }^{11)}$ levels of mRNA transcribed from the $R A m y 3 D$ gene ${ }^{12,15)}$ and the promoter activity. ${ }^{13)}$

We also examined the effects of other sugars related to cellular metabolism on the expression of the isoforms (panel B in Fig. 3). From a comparison of the patterns of the isoforms cultured in sucrose-free (lanes 1-3) and sucrosecontaining (lanes 4-6) medium, the samples on day 3 of incubation (lanes 2 and 5) seemed to be most suitable for the detection of isoforms synthesized in the presence of sugars. Glucose (lane 8), fructose (lane 9) and maltose (lane 10) were effective in repressing all of the isoforms, as was sucrose (lane 5). In the case of incubation with a solution of starch, only the $R A m y 1 A$-encoded protein (isoform A) was synthesized (lane 7), and the pattern was similar to that of the isoforms obtained in germinating seeds (lanes 2 and 3 in Fig. 1). Several isoforms, but with lower activities than in the sucrose-free medium (control, lane 2), were detected when galactose, glycerol, lactose and mannose (lanes 11, 12, 13 and 14, respectively) were present. To determine whether or not the repression and derepression on the isoforms is reversible, cells were grown in sucrose-free medium for 3 days, then in sucrose-containing medium for an additional 3 days, and then this cycle was repeated (Fig. 4). The activity of isoforms $\mathrm{A}-\mathrm{J}$ increased in sucrose-free medium (lanes 1-3) and then decreased after incubation of the cells in sucrose-containing medium (lanes $3-5)$. The phenomenon was repeated during the second cycle (lanes 5-9). These results indicate that the repression and derepression of the isoforms are reversible depending on the presence or absence of sucrose, in agreement with the results for total $\alpha$-amylase protein. ${ }^{11}$

cDNA clones for the RAmy1A and RAmy3D genes of rice $\alpha$-amylase were characterized by O'Neil et al. ${ }^{28)}$ Because the results in Fig. 2

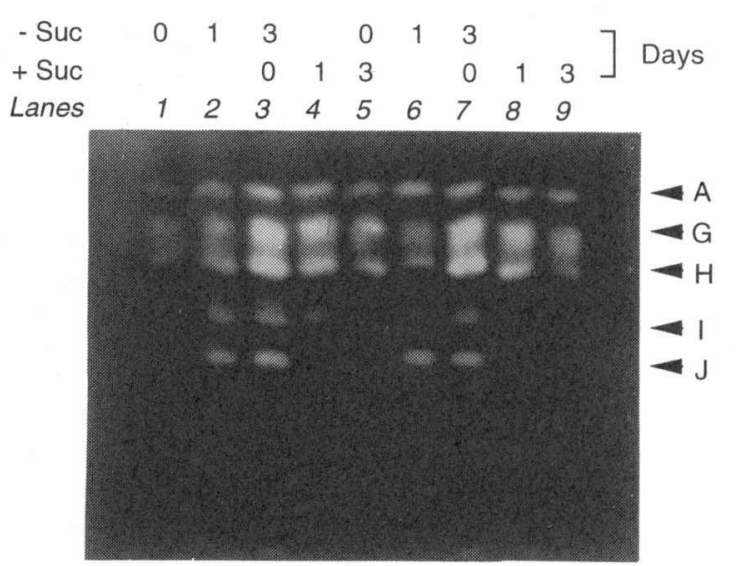

Fig. 4. Reversibility of the repression and derepression of the synthesis of isoforms A-J.

Suspension-cultured cells of rice were transferred to sucrose-free medium and cultured for 0,1 and 3 days (lanes 1, 2 and 3, respectively). Then, cells were washed and transferred to fresh medium that contained $0.09 \mathrm{M}$ sucrose and cultured for an additional 3 days, (lanes 3-5). The same culture system was examined for an additional cycle (lanes 5-9). Collected cells were homogenized, samples (15 $\mu \mathrm{g}$ protein) were subjected to isoelectric focusing ( $\mathrm{pH}$ 3.5-9.5) and the gel was stained after incubation with $\beta$-limit dextrin.

and in panel B of Fig. 3 suggested differences in regulation between proteins encoded by $R A m y 1 A$ and $R A m y 3 D$, we tried to quantify the levels of respective mRNAs after sucrose depletion using the cDNA clones as probes. Cells were transferred to either sucrose-containing medium or sucrose-free medium and incubated for 6 and $24 \mathrm{~h}$. Because OS103 (cDNA of $R A m y 1 A)$ and OS137 (RAmy3D), used as probes, have $76 \%$ homology at the amino acid sequence level, ${ }^{28)}$ we used highly stringent hybridization conditions for removal of the nonspecific probe to avoid cross-contamination, as shown in lanes 5 and 6 in both panels $A$ and $B$ of Fig. 5. With sucrose in the medium, the levels of both OS103 and OS137 mRNAs were low during $6 \mathrm{~h}$ (lane 1) and $24 \mathrm{~h}$ (lane 2) incubation. Without sucrose in the medium, the levels of both mRNAs increased. However, the increase in OS137 mRNA (RAmy3D) was much greater (panel B, lanes 3-4) than that in OS103 mRNA $(R A m y 1 A)$ (panel A, lanes 3-4). These results agree well with those at the protein level (Fig. 
A
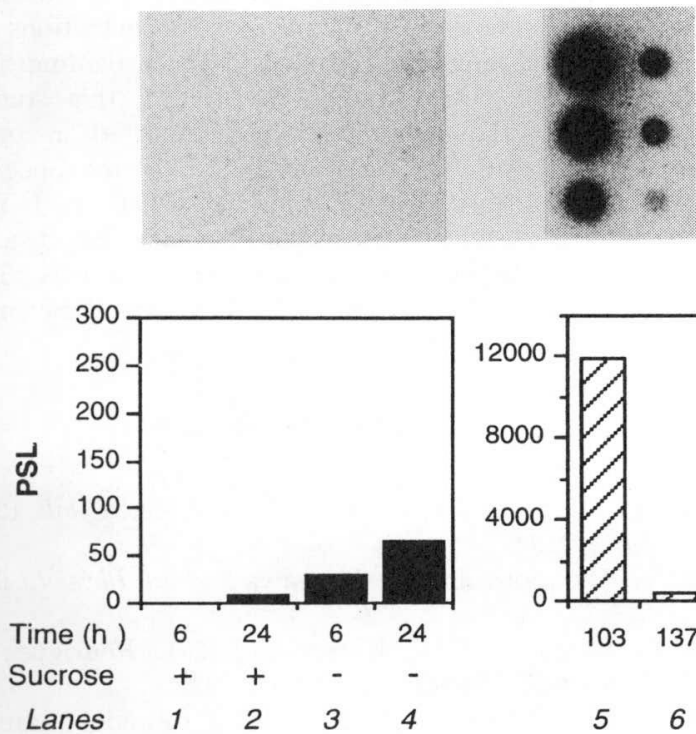

pOS 103 (RAmy1A)

56
B
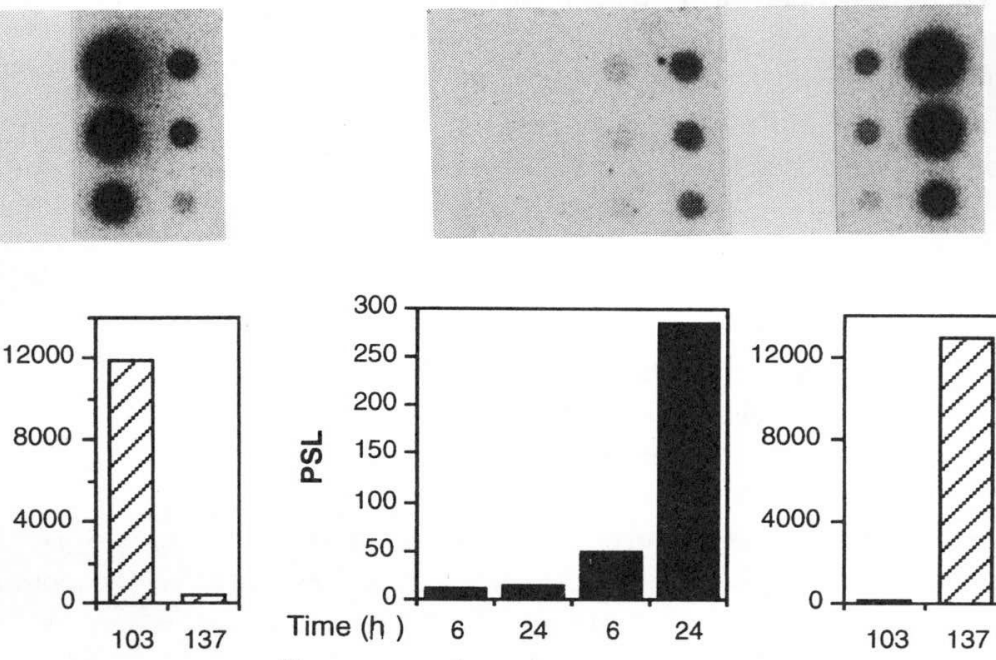
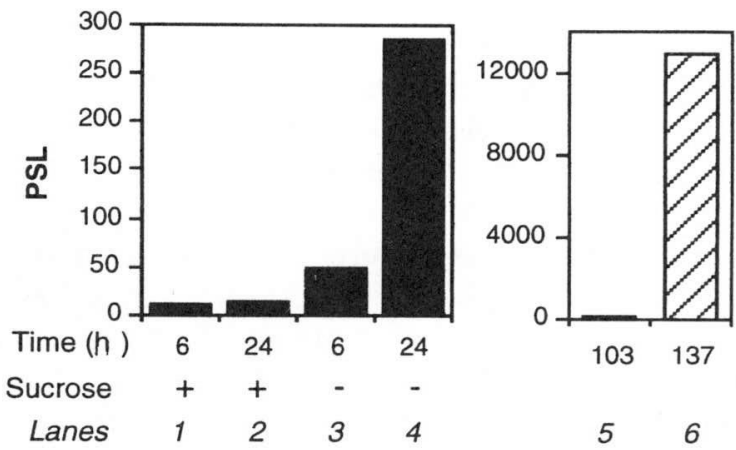

5

6

pOS 137 (RAmy3D)

Fig. 5. Effects of sugar depletion on levels of mRNAs transcribed from the $R A m y 1 A$ and $R A m y 3 D$ genes for $\alpha$-amylase.

Suspension-cultured cells of rice were transferred to either sucrose-containing $(0.09 \mathrm{M})$ or sucrose-free medium and culturing was continued for an additional 6 or $24 \mathrm{~h}$. RNA was isolated from harvested cells and subjected to dot blot analysis with either cDNA for RAmy1A (pOS103; panel A) or cDNA for RAmy3D (pOS137; panel B), as described in the text. Upper panel: Total RNA (40,20,10 $\mu \mathrm{g}$, from top to bottom) was blotted onto a Nytran membrane and hybridized with ${ }^{32} \mathrm{P}$-labeled pOS103 (panel A; lanes 1-4) or pOS137 (panel B; lanes 1-4). To detect cross-hybridization, which is a negative index for gene-specific detection, $200 \mathrm{pg}, 100 \mathrm{pg}$ or $50 \mathrm{pg}$ (from top to bottom) of the cDNA of pOS103 (panel A) and pOS137 (panel B) were allowed to hybridize with ${ }^{32}$ P-labeled pOS103 (lane 5 in both panels) and pOS137 (lane 6). Lower panel: Radioactivity from the dot blot analysis (upper panel) was measured with an image analyzer. PSL, The units used by the analyzer, are directly proportional to standard units, such as bequerels, curies and dpm.

3). Therefore, we confirmed that the difference in regulation between $R A m y 1 A$-encoded protein and $R A$ my $3 D$-encoded protein by metabolizable sugars occurs at the transcriptional level, as well as at the protein level.

\section{DISCUSSION}

Multiple genes for $\alpha$-amylases in cereals are classified into three major groups: Amy1, Amy2 and Amy3. ${ }^{6}$ Six Amy3 genes in the Amy3 subfamily are found among the ten genes for $\alpha$ amylases identified in rice, while no or only a single Amy3 gene has been characterized among many genes for members of the Amy1 and Amy2 subfamilies in barley and wheat, respectively. ${ }^{6)}$ The translated proteins from the Amy1 and Amy2 genes, designated as high$\mathrm{p} I$ and low-p $I$ proteins, respectively, are detected in germinating seeds. ${ }^{1)}$ However, the genes of the Amy3 in rice and their translated products have not been well characterized. From a comparison of the isoforms of rice $\alpha$-amylases in this study, it appears that the expression of the $R A m y 3 D$-encoded protein is distinct from that of the $R A m y 1 A$-encoded protein for the following reasons. (1) The $R A m y I A$ gene was expressed as an active enzyme (isoform A) in germinating seeds, while $R A m y 3 D$ (isoforms $\mathrm{G}$ and $\mathrm{H}$ ) was not (see lanes 2 and 3 in Fig. 1). (2) Expression of the $R A m y 3 D$-encoded protein in suspension-cultured cells was regulated 
by metabolizable sugars, while that of the $R A m y 1 A$-encoded protein was found to be less sensitive to such sugars (Figs. 2 and 3 ). The level of mRNA transcribed from $R A m y 3 D$ in suspension-cultured cells increased considerably in the absence of sucrose, while that of $R A m y 1 A$ did respond but to a lesser extent to such conditions (Fig.5). The conclusion derived from protein analyses in this study is consistent with that from the promoter and Northern analyses. ${ }^{16)}$ Differences between the $R A m y 1 A$ - and $R A m y 3 D$-encoded proteins are also suggested by differences in protein chemistry as follows. (1) Isoform $\mathrm{H}(R A m y 3 D$-encoded protein) has different properties from isoform $\mathrm{A}$ ( $R A m y 1 A$-encoded protein) in terms of activity in the presence of divalent cations and stability to heat treatment. ${ }^{10,27,29)}$ (2) The $R A m y 1 A$-encoded protein has been reported as a $N$-linked complex-type glycoprotein containing xylose as well as mannose and $N$-acetylglucosamine, ${ }^{25)}$ while, in the case of $R A m y 3 D$. encoded protein, no potential sites of $N$-linked glycosylation (Asp-X-Ser or Thr) can be deduced from the cDNA sequence of $R A m y 3 D .^{28)}$ Overall, our results indicate that the $R A m y 1 A$ encoded protein plays an important role in the degradation of starch reserves during germination, while the $R A m y 3 D$-encoded protein plays some other distinct role (s).

$\alpha$-Amylase plays a major role during the degradation of mature starch granules, ${ }^{9}$ ) although only through the concerted action of $\alpha$-amylase, $\alpha$-amylase, ${ }^{30}$ debranching enzyme and $\alpha$-glucosidase, starch is hydrolyzed completely. ${ }^{2,31)}$ Perata et al. ${ }^{32)}$ have reported that even barley $\alpha$-amylase genes (both high and low $\mathrm{p} I$ group) are under control in the embryo (but not in the aleurone), indicating that $\alpha$ amylase may be generally under sugar control in the embryos. The physiological significance of sugar repression of $\alpha$-amylase production, especially in the epithelium, is unclear; although it is tempting to speculate that it may trigger an important functional switch in the physiological role of the epithelium (or embryo), from the initial secretion of $\dot{\alpha}$-amylases to absorbing degradation products from endosperm reserves.
The authors thank Dr. P. Perata (University of Pisa, Italy) and Dr. R. L. Rodriguez (University of California, Davis) for guidance in the assays of concentrations of sugars, stimulating discussions and for providing the cDNA clones (pOS103 and 137) used in this study, respectively. This research was supported in part by Grants-in-Aid No. 05276102 (to J. Y.) for Special Research on Priority Areas and No. 07660006 (to J. Y.) from the Ministry of Education, Science, Sport and Culture (Monbusho), Japan. This research was also supported in part by Iijima Memorial Food Science Foundation (to J. Y.).

\section{REFERENCES}

1) R. L. Jones and J. V. Jacobsen : Int. Rev. Cytol., 126, 49-88 (1991).

2) K. Okamoto and T. Akazawa : Plant Physiol., 63, 336-340 (1979).

3) S. Ranjahan, E. E. Karrer and R. L. Rodriguez : Plant Cell Physiol., 33, 73-79 (1992).

4) N. Sugimoto, G. Takeda, Y. Nagato and J. Yamaguchi : Plant Cell Physiol., 14, 148-150 (1998).

5) K. Itoh, J. Yamaguchi, N. Huang, R. L. Rodoriguez, T. Akazawa and K. Shimamoto: Plant Physiol., 107, 25-31 (1995)

6) N. Huang, G. L. Stebbins and R. L. Rodriguez: Proc. Natl. Acad. Sci. USA., 89, 7526-7530 (1992).

7) S.-M. Yu, Y.-C. Lee, S.-C. Fang, M.-T. Chan, S.-F. Hwa and L.-F. Liu : Plant Mol. Biol., 30, 1277-1289 (1996).

8) B. Khursheed and J. C. Rogers : Proc. Natl. Acad. Sci. USA, 86, 3987-3991 (1989).

9) P. Perata, J. Pozueta-Romero, T. Akazawa and J. Yamaguchi : Planta, 188, 611-618 (1992).

10) T. Mitsui, J. Yamaguchi and T. Akazawa : Plant Physiol., 110, 1395-1404 (1996)

11) S.-M. Yu, Y.-H. Kuo, G. Sheu, Y.-J. Sheu and L.-F. Liu : J. Biol. Chem., 266, 21131-21137 (1991).

12) E. E. Karrer, and R. L. Rodriguez : Plant J., 2, 517523. (1992).

13) T. Umemura, P. Perata, Y. Futsuhara and J. Yamaguchi : Planta, 204, 420-428 (1998).

14) N. Huang, J. Chander, B. R. Thomas, N. Koizumi and R. L. Rodriguez: Plant Mol. Biol., 23, 737-747 (1993).

15) K. Toyofuku, T. Umemura and J. Yamaguchi : FEBS Lett., 428, 275-280 (1998).

16) A. Morita, T. Umemura, M. Kuroyanagi, Y. Futsuhara, P. Perata and J. Yamaguchi : FEBS Lett., 423, 81-85 (1998).

17) J. Kyozuka, Y. Hayashi and K. Shimamoto : Mol. Gen. Genet., 206, 408-413 (1987).

18) K. Ohira, K. Ojima and A. Fujiwara : Plant Cell Physiol., 14, 1113-1121 (1973).

19) T. Murashige and F. Skoog : Plant Physiol., 15, 473497 (1962). 
20) E. E. Karrer, J. C. Litts and R. L. Rodriguez : Plant Mol. Biol., 16, 797-805 (1991).

21) P. Perata, N. Geshi, J. Yamaguchi and T. Akazawa: Planta, 191, 402-408 (1993).

22) L. Guglielminetti, J. Yamaguchi, P. Perata and A. Alpi : Plant Physiol., 109, 1069-1076 (1995).

23) S. Mitsunaga and J. Yamaguchi : Plant Cell Physiol., 34, 243-249 (1993).

24) J. Yamaguchi : Breeding Sci., 48, 365-370 (1998).

25) M. Hayashi, A. Tsuru, T. Mitsui, N. Takahashi, H. Hanzawa, Y. Arata and T. Akazawa: Eur. J. Biochem., 191, 287-295 (1990).

26) C. R. Simmons, N. Huang, Y. Cao and R. L. Rodriguez: Biotech. Bioeng., 38, 545-551 (1991).

27) T. Mitsui, Y. Ueki and K. Igaue : Plant Physiol. Biochem., 31, 863-874 (1993).

28) S. O'Neil, M. H. Kumagai, A. Majumdar, N. Huang, T. D. Sutliff and R. L. Rodriguez : Mol. Gen. Genet., 221, 235-244 (1990).

29) M. Terashima, N. Hayashi, B. R. Thomas, R. L. Rodriguez and S. Katoh: Plant Sci., 116, 9-14 (1996).

30) J. Yamaguchi, S. Itoh, T. Saitoh, A. Ikeda, T. Tashiro and Y. Nagato: Theor. Appl. Genet., 98, 32-38 (1999).

31) Z. Sun and C. A. Henson: Arch. Biochem. Biophys., 284, 298-305 (1991).

32) P. Perata, C. Matsukura, P. Verinieri and J. Yamaguchi : Plant Cell, 9, 2197-2208 (1997).

(Received October 20, 1998; Accepted December 15, 1998)
イネ培養細胞における 2 種類の $\alpha$-アミラーゼ

アイソフォームの糖による発現制御の差異

下司直美, 三ツ井敏明 ${ }^{1}$, 赤沢 堯, 山口淳二

名古屋大学生物分子応答研究センター・生命農学

研究科（464-8601 名古屋市千種区不老町）

${ }^{1}$ 新潟大学農学応用生物化学科

(950-2181 新潟市五十嵐 2 の町 8050)

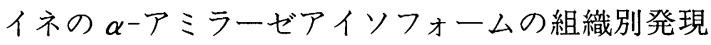
と培養細胞を用いた糖による合成抑制現象について解 析した。各種のイネの組織を用いたザイモグラム解析 によって, 主に 6 種類の $\alpha$-アミラーゼアイソフォー ム, すなわちアイソフォーム $\mathrm{Y}, \mathrm{A}, \mathrm{G}, \mathrm{H}, \mathrm{I}$ と J が確 認され，その内， $\mathrm{A}$ は発芽種子で，Y は幼植物で， $\mathrm{A}-\mathrm{J}$ は培養細胞での主要なアイソフォームであった。精 製後のアミノ酸配列の決定の結果から，アイソフォー 厶 $\mathrm{A}$ は $R A m y 1 A$, アイソフォーム $\mathrm{H}$ は $R A m y 3 D$ 遺 伝子の翻訳産物であることが明らかとなっている (Plant Physiol., 110, 1395-1404 (1996)). イネの $\alpha^{-}$ アミラーゼ遺伝子が糖によって転写抑制を受けること がよく知られていることから，これらのアイソフォー 么の糖応答性について解析を加えた。 $R A m y 3 D$ 翻訳 産物（アイソフォーム $\mathrm{H}$ ） は代謝される糖によって完 全に合成が阻害されるのに対して，RAmy $1 A$ 翻訳産 物（アイソフォームA）は，その合成が糖による阻害 を受けるものの，RAmy $3 D$ 翻訳産物に比べるとその 阻害程度が緩やかであった。両タンパク質の発牙時に おける生理的意義について考察した。 